\title{
Insights into microbe mediated arsenic release to groundwater focusing on Bangladesh and India
}

\begin{abstract}
Arsenic (As) contamination of ground water is a potential threat to human population in several countries throughout the world. Subsurface aquifer sediments act as the principle source point of arsenic pollution in ground water. Microbial activities have been reported to influence As release and speciation in the groundwater from the subsurface sediments. One of the most important group of microorganisms responsible is the dissimilatory arsenate reducing prokaryotes (DARP) which use arsenate as electron acceptor and solubilize arsenic from sediments. Several genes are responsible for metabolism of As (III/V) and thus to release of As from sediments, such as arr (dissimilatory arsenate reductase gene) and ars genes (arsenate reductase). These genes have been found to be distributed across diverse phylogenetic population. Several recent studies have also pointed to the role of organic matter in the release of As from the sediments, which has led to a huge scope for research in relation to metatranscriptomic analysis of arsenate reduction.
\end{abstract}

Keywords: arsenic, aquifer, DARP, electron acceptor
Volume 2 Issue 4 - 2016

\author{
Shilajit Barua,' Subhankar Barua,' Jishnu \\ Adhikari $^{2}$ \\ 'Department of Microbiology and Research and Development \\ Centre,Vijaygarh Jyotish Ray College, India \\ ${ }^{2}$ Department of Geological Sciences and Environmental Studies, \\ Binghamton University, USA
}

Correspondence: Shilajit Barua, Department of Microbiology \& Research and Development Centre,Vijaygarh Jyotish Ray College, 8/2 Bejoygarh, Jadavpur, Kolkata, India, Tel +919432166493, Email shilajit_26@yahoo.co.in

Received: July 05, 2016 | Published: August 05, 2016

\section{Introduction}

Contamination of ground water by arsenic is a major problem in many countries throughout the world. ${ }^{1}$ This potentially geogenic origin toxin, carcinogen and teratogen gains entry into human food chain via contaminated drinking water or food crops cultivated in contaminated soils. ${ }^{2}$ Several regions of the world like are affected by groundwater and pollution of arsenic. Concentration of arsenic in aquifers from Argentina, Bangladesh, Chile, China, Hungary, India (West Bengal), Mexico, Romania, Vietnam, Nepal, Myanmar, Cambodia, and the United States, have been reported to possess arsenic at concentrations above $0.05 \mathrm{mg} / \mathrm{L} .{ }^{3}$ Among these, about 105,000 square $\mathrm{km}$ region in deltaic plains of India and Bangladesh has been reported to be worstly affected by this geogenic pollution. ${ }^{4}$ About 70 million people residing in this region are exposed to various As related chronic health problems from drinking As-rich groundwater. ${ }^{5}$ Groundwater obtained from the Holocene-aged-aquifers in Bangladesh have much higher level of arsenic. ${ }^{6}$ Apart from Bangladesh and India, several countries around the world has reported elevated concentrations of As in groundwater such as Taiwan, ${ }^{7}$ PR China (e.g. Shanxi, Xinjiang, and Inner Mongolia), ${ }^{8,9}$ Vietnam, ${ }^{10}$ USA (New Jersey). ${ }^{11}$

Aquifers are deep subsurface layers of rocks, sand or soil capable of storing and transmitting water. Sources of groundwater includes horizontal flow within an aquifer, vertical flow between adjacent aquifers, point and line sources and diffuse recharge of aquifers. ${ }^{12}$

Arsenic occurs with valence states of- 3 (arsine, $\mathrm{AsH}_{3}$ ), 0 (metallic, As0), +3 (arsenite, $\mathrm{As}[\mathrm{OH}]_{3}$ ) and +5 (arsenate, $\mathrm{AsO}_{-3}$ ) depending on the environmental conditions. Arsenate $(\mathrm{As}[\mathrm{V}])$ is the predominant form in soil and surface water, while reducing conditions in anaerobic groundwater favours the occurance of arsenite (As[III]). Reduction of AsV to AsIII results in solubilization of arsenic from sediments leading to arsenic contamination of groundwater. ${ }^{13}$
Among the various factors like various anthropogenic sources, competitive adsorption/desorption of anions on metal hydroxides release from sulfide minerals (i.e., arsenopyrite) and from phosphate fertilizers, ${ }^{14}$ microorganisms like metal-reducing bacteria had often been related to arsenic release from soils and sediments. ${ }^{13}$ Among the several proposed mechanisms of arsenic release from soil and sediments, dissimilatory arsenate reduction is considered to be the principle one under anoxic condition such as deep aquifer ecosystem, ${ }^{15}$ a source point of groundwater.

Two types of arsenate reductase have been reported in prokaryotes. Cytoplasmic arsenate reductase is a detoxifying enzyme that reduces AsV to AsIII followed by extrusion of arsenite from the cell. Microbes harbouring this type of cytoplasmic arsenate reductase was first arsenate reducers to be discovered and being one of the resistant mechanisms adopted, such group of microbes were referred to as arsenate resistant microbes (ARM). Further molecular analysis of this process revealed the role of ars RBCoperon system performing arsenate binding (ArsR), arsenate reductase (ArsB) and arsenite efflux (ArsC) respectively..$^{14}$ However, this system is active only on AsV that has entered the cell and not on those that remain adsorbed to Fe(III) in sediments. ${ }^{16}$

Dissimilatory arsenate reduction is carried out by a group of arsenic metabolizing bacteria called dissimilatory arsenate reducing prokaryotes (DARP) $)^{17}$ which carries out anaerobic respiration by using $\mathrm{AsV}$ as terminal electron acceptor. The first arsenate-respiring bacterium (strain MIT-1) was isolated from anoxic sediments of Aberjona watershed in eastern Massachusetts, ${ }^{18}$ was later identified as Geospirillumarsenophilus ${ }^{19}$ and was the first member of dissimilatory arsenate respiring prokaryotes (DARPs) to be reported.

DARPs represents to diverse phylogenetic groups such as Firmicutes, Gamma-, Delta- and Epsilonproteobacteria, Aquificae, Deferribacteres, Chryosiogenetes and in the Archaea. ${ }^{14}$ Molecular analysis revealed that anaerobic dissimilatory $\mathrm{As}(\mathrm{V})$ reduction is 
catalyzed by the periplasmic arsenate respiratory reductase (Arr) complex, which consists of a large catalytic subunit (ArrA) and a small subunit (ArrB). ${ }^{20}$ As per Malasarn et al..${ }^{21}$ the arrA gene encoding large subunit of the reductase can be used as a reliable marker for arsenate respiration. Uniquely, the Arr enzyme also has been demonstrated to bebidirectional; it shows both arsenate reductase and arsenite oxidase activity in vitro depending on its electron potential and the constituents of the electron transfer chain. ${ }^{22}$ Figure 1 depicts various microbial gene products in arsenic species transformation.

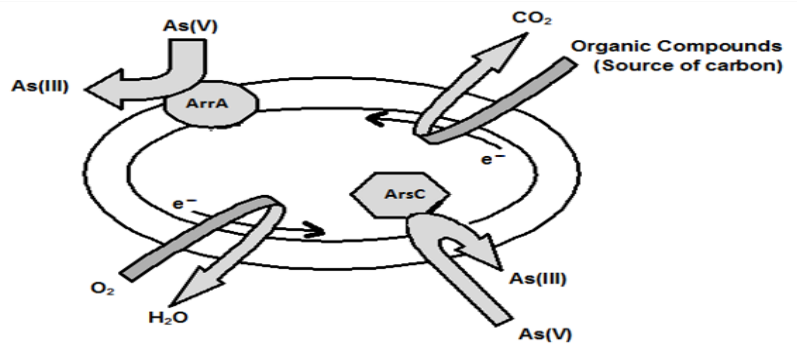

(ArrA: Dissimilatory Respiratory Arsenate Reductase; ArsC: Cytoplasmic Arsenate Reductase)

Figure I Biochemical transformations of arsenic oxyanions by microbial cells.

The release of arsenic from aquifer sediments is most commonly associated with a transition from oxic to anoxic conditions..$^{23,15}$ Anoxic and chemically-reducing conditions promote the reductive dissolution of iron oxide minerals that adsorb As, and also promote bacteriallymediated reduction of sediment-bound As from the more sorptive pentavalent oxyanion arsenate $[\mathrm{As}(\mathrm{V})]$ to the more soluble and mobile trivalent form, arsenite [As(III)] (Figure 2).

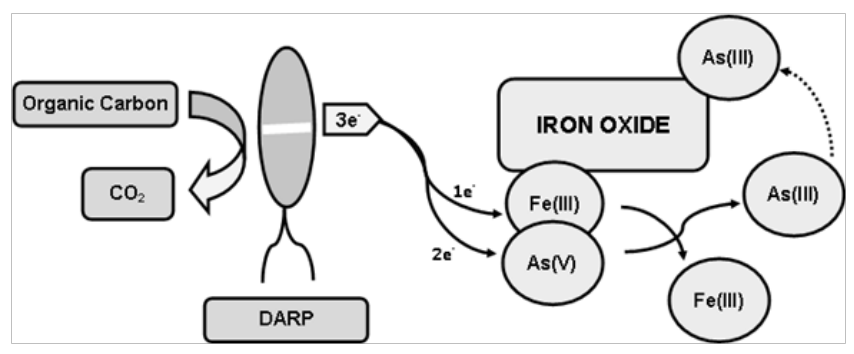

Figure 2 Bacteria mediated reduction and release of sediment-bound As.

In natural settings, the reductive dissolution of Fe-oxide minerals and reductive mobilization of As(III) are largely mediated by phylogenetically and physiologically diverse prokaryotes that obtain metabolic energy by coupling the reduction of $\mathrm{Fe}(\mathrm{III})$ or $\mathrm{As}(\mathrm{V})$ to dissolved organic matter or chemoautotrophic electron donors such as sulfide. ${ }^{24,25}$ Hence, in addition to the detoxifying cytoplasmic arsenate reduction and expulsion, geomicrobiological $\mathrm{Fe}(\mathrm{III})$ and $\mathrm{As}(\mathrm{V})$ reduction by DAPR, thereby act both individually and in combination to release As from sediments to the dissolved phase of ground water. ${ }^{26,27}$ Expression of arrA was first studied in Shewanella $s p$. strain ANA-3, wherein the protein was expressed at the beginning of the exponential phase and persist till the end of stationary phase. ${ }^{28}$ Induction of ArrA expression was observed in presence of arsenate and acetate but no such activity was observed in presence of electron donors like antimonite, nitrate, selanate or Sulphur. This study was carried out in $\mathrm{Fe}(\mathrm{III})$ reducing bacteria Geobacterlovleyi indicating its possible role in release of arsenic from aquifer sediments into groundwater. ${ }^{29}$
Recent investigations indicated organic matter as a determining factor for abundance and diversity of arsenate respiring bacteria in sediments. In a microcosm based study on Pleistocene and Holocene sediments, addition ${ }^{13} \mathrm{C}$-acetate and ${ }^{13} \mathrm{C}$-lactate exhibited abundance of different active bacterial community and also difference in quantitative arsenic release from sediments. ${ }^{30}$ At sites with varying hydrology, utilization of relatively young carbon sources by the subsurface microbial community was recently reported. These young carbon sources drive microbial metabolism that induced Fe reduction with concomitant release of As from sediments implied introduction of such carbon sources to unaffected sediments could stimulate microbial communities thereby favoring arsenic release. ${ }^{31}$

Several culture independent studies depicting metagenomics distribution and abundance of arrA gene in diverse ecological habitats has been carried out. ${ }^{32-34}$ However, most of the studies related to activity and expression of arrA gene had been confined to culture based pure culture techniques which does not depicts the real picture in real ecological niches. An alternate and more logical approach would be analysis of the transcription profile of arrA gene of the whole DARP community in situ in various aquifer ecosystems. Hence culture independent metatranscriptomic (analysis of whole community gene expression profile) approaches are to be undertaken to reveal the real picture and determine the governing ecological factors for arsenic release from aquifer sediments to ground water.

\section{Acknowledgements}

The authors are in debt to Prof. Debasish Chatterjee, Department of Chemistry, University of Kalyani, India for his indepth knowledge sharing related to this work. Financial support by SERB, Govt. of India in carrying out allied research is also deeply acknowledged. Infrastructural support to the author is provided by host institution, Vijaygarh Jyotish Ray College needs special mention.

\section{Conflict of interest}

The author declares no conflict of interest.

\section{References}

1. Bhattacharya P, Jacks G, Jana J, et al. Geochemistry of the holocene alluvial sediments of bengal delta plain from west bengal, india: implications on arsenic contamination in groundwater. Groundwater arsenic contamination in the Bengal Delta Plain of Bangladesh. 2001;3084:21-40.

2. Huq SM, Joardar JC, Parvin S, et al. Arsenic contamination in food-chain: transfer of arsenic into food materials through groundwater irrigation. $J$ Health Popul Nutr. 2006;24(3):305-316.

3. Smedley PL, Kinniburgh DG. A review of the source, behaviour and distribution of arsenic in natural waters. Applied geochemistry. 2002;17(5):517-568.

4. Mukherjee AB, Bhattacharya P. Arsenic in groundwater in the bengal delta plain: slow poisoning in Bangladesh. Environmental Reviews. 2001;9(3):189-220.

5. GuhaMazumder DN. Chronic arsenic toxicity: clinical features, epidemiology, and treatment: experience in West Bengal. J Environ Sci Health A Tox Hazard Subst Environ Eng. 2003;38(1):141-163.

6. Ahmed MF, Ahuja S, Alauddin M, et al. Ensuring safe drinking water in Bangladesh. Science. 2006;314(5806):1687-1688.

7. Chen CJ. Emerging epidemics of arseniasis in Asia. Arsenic Exposure and Health Effects. In: Chappell WR, Abemathy CO, Calderon RL, editors. New York: Elsevier Science; 1999. p. 113-121. 
8. Wang GQ. Endemic arsenism, fluorosis and arsenic-fluoride poisoning caused by drinking water in Kuitun, Xinjiang. Chinese Medical Journal. 2000;113(6):524-524.

9. Guo X, Fujino Y, Kaneko S, et al. Arsenic contamination of groundwater and prevalence of arsenical dermatosis in the Hetao plain area, Inner Mongolia, China. Mol Cell Biochem. 2001;222(1-2):137-140.

10. Berg M, Tran HC, Nguyen TC, et al. Arsenic contamination of groundwater and drinking water in Vietnam: a human health threat". Environ Sci Technol. 2001;35(13):2621-2626.

11. Page GW. Comparison of groundwater and surface water for patterns and levels of contamination by toxic substances. Environmental science \& technology. 1981;15(12):1475-1481.

12. Armstrong D, Narayan K. Groundwater processes and modelling Australia: Csiro Publishing; 1998. 24 p.

13. Oremland RS, Stolz JF. Arsenic, microbes and contaminated aquifers. Trends in microbiology. 2005;13(2):45-49.

14. Cavalca L, Corsini A, Zaccheo P, et al. Microbial transformations of arsenic: perspectives for biological removal of arsenic from water. Future microbiol. 2013;8(6):753-768.

15. Islam FS, Gault AG, Boothman C, et al. Role of metal-reducing bacteria in arsenic release from Bengal delta sediments. Nature. 2004;430(6995):6871.

16. Langner HW, Inskeep WP. Microbial reduction of arsenate in the presence of ferrihydrite. Environmental Science \& Technology. 2000;34(15):31313136 .

17. Kruger MC, Bertin PN, Heipieper HJ, et al. Bacterial metabolism of environmental arsenic-mechanisms and biotechnological applications. Appl Microbiol Biotechnol. 2013;97(9):3827-3841.

18. Ahmann D, Roberts AL, Krumholz LR, et al. Microbe grows by reducing arsenic. Nature. 1994;371(6500):750.

19. Lovley DR, Coates JD. Bioremediation of metal contamination. Curr Opin Biotechnol. 1997;8(3):285-289.

20. Van Lis R, Nitschke W, Duval S, et al. Arsenics as bioenergetic substrates. Biochim Biophys Acta. 2013;1827(2):176-188.

21. Malasarn D, Saltikov CW, Campbell KM, et al. arrA is a reliable marker for As (V) respiration. Science. 2004;306(5695):455.

22. Richey C, Chovanec P, Hoeft SE, et al. Respiratory arsenate reductase as a bidirectional enzyme. Biochem Biophys Res Commun. 2009;382(2):298302 .
23. Oremland RS, Hoeft SE, Santini JM, et al. Anaerobic oxidation of arsenite in Mono Lake water and by a facultative, arsenite-oxidizing chemoautotroph, strain MLHE-1. Appl Environ Microbiol. 2002;68(10):4795-4802.

24. Stolz JF, Oremland RS. Bacterial respiration of arsenic and selenium. FEMS microbiol Rev. 1999;23(5):615-627.

25. Stolz JF, Basu P, Santini JM, et al. Arsenic and Selenium in Microbial Metabolism. Annu Rev Microbiol. 2006;60:107-130.

26. Katharine JT, Carolina R, Chad WS, et al. Reductive processes controlling arsenic retention: revealing the relative importance of iron and arsenic reduction. Environmental science \& technology. 2008;42(22):8283-8289.

27. Osborne TH, McArthur JM, Sikdar PK, et al. Isolation of an arsenaterespiring bacterium from a redox front in an arsenic-polluted aquifer in West Bengal, Bengal Basin. Environ Sci Technol. 2015;49(7):4193-4199.

28. Malasarn D, Keeffe JR, Newman DK. Characterization of the arsenate respiratory reductase from Shewanella $s p$. strain ANA-3. J Bacteriol. 2008;190(1):135-142.

29. Giloteaux L, Holmes DE, Williams $\mathrm{KH}$, et al. Characterization and transcription of arsenic respiration and resistance genes during in situ uranium bioremediation. ISME J. 2013;7(2):370-383.

30. Héry M, Rizoulis A, Sanguin H, et al. Microbial ecology of arsenic mobilizing Cambodian sediments: lithological controls uncovered by stable $\square$ isotope probing. Environ Microbiol. 2015;17(6):1857-1869.

31. Whaley Martin KJ, Mailloux BJ, van Geen A, et al. Stimulation of microbially-mediated arsenic release in bangladesh aquifers by young carbon indicated by radiocarbon analysis of sedimentary bacterial lipids. Environ Sci Technol. 2016;50(14):7353-7363.

32. Zhang SY, Zhao FJ, Sun GX, et al. Diversity and abundance of arsenic biotransformation genes in paddy soils from Southern China. Environ Sci Technol. 2015;49(7):4138-4146.

33. Desoeuvre A, Casiot C, Héry M. Diversity and distribution of arsenicrelated genes along a pollution gradient in a river affected by acid mine drainage. Microb Ecol. 2016;71(3):672-685.

34. Xiao KQ, Li LG, Ma LP, et al. Metagenomic analysis revealed highly diverse microbial arsenic metabolism genes in paddy soils with lowarsenic contents. Environ Pollut. 2016;211:1-8. 